\title{
BLDC MOTOROK 3D-S SZIMULÁCIÓJA
}

\author{
Erdősy Dániel \\ tanársegéd, Miskolci Egyetem, Gépészmérnöki és Informatikai Kar, Fizikai és Elektrotechnikai Intézet, \\ Elektrotechnikai és Elektronikai Intézeti Tanszék \\ 3515 Miskolc, Miskolc-Egyetemváros, e-mail: elkedani@uni-miskolc.hu
}

\begin{abstract}
Absztrakt
A kefe nélküli egyenáramú motorok (BLDC motorok) egyre inkább elterjedtek a legkülönbözöbb alkalmazásokban. A cikkem alapját egy autóipari hütőventilátor motor adja, amelynek elektromágneses emisszió szintjét igyekszünk csökkenteni egy projekt keretén belül. A cikkben ezen motor felépitéséröl, lehetséges problémáiról, térbeli szimulációjáról lesz szó. A modell egyszerüsitési lehetőségei, valamint az eddig feltárt szimulációs eredményei is megjelennek a cikkben. A modell az ANSYS nevü programban kerül vizsgálat alá, ahol az egyszerü mágneses szimulációktól, a valós müködés közben fellépö jelenségekig képesek lehetünk vizsgálni ezt a motort.
\end{abstract}

Kulcsszavak: BLDC motor, kefe nélküli egyenáramú motor, elektromágneses szimuláció, ANSYS

\section{Abstract}

Brushless direct current motors (BLDC motors) are commonly used in a wide variety of applications. The base of my article is an automotive cooling fan motor, which we want to reduce the electromagnetic emission in a project. This article is mainly about the structure, the possible problem and the $3 D$ simulation of the mentioned motor. The article also contains some solutions how to simplify the $3 D$ model, and what are the results I could have achieved till now. The 3D model is under examination in ANSYS software, in which from simple magnetic fields to real-life phenomenon can be simulated.

Keywords: BLDC motor, brushless direct current motor, electromagnetic simulation, ANSYS

\section{Bevezetés}

A kefe nélküli egyenáramú motoroknak számtalan előnyét ismerjük. A félvezető elemek árának csökkenésével, teljesítményük és kapcsolási sebességük növekedésével számtalan különböző alkalmazásban találkozhatunk velük [1].

A cikk alapját egy autóipari hütőventilátor motor adja. Ezen a területen a motor alakja, teljesítménye, a jármüvekben jelenlévő tápfeszültség, valamint a vezérelhetőség miatt ideális választás a BLDC motor [1]. Egy projekt keretein belül ennek a motornak kell az elektromágneses kompatibilitását javítani, emiatt a motorról 3D-s szimulációt készítek. A szimulációk elkészítéséhez az ANSYS Electronics Desktop programot használom. Mivel a projekt keretein belül EMC méréseket is végeztünk ezen az egységen, így a probléma egyes tulajdonságait is jobban megismerhettem.

\subsection{A motor felépítése}

Egy „fazék alakú” forgórésszel, valamint benne 2 fázisra tekercselt állórésszel rendelkezik. A ventilátorlapát közvetlenül a forgórészre van szerelve, így az egész egység keskeny lehet. A motor elektronikus vezérlése a motor alaplemeze alatt helyezkedik el, így kívülről csak a tápfeszültséget (12V DC), 
valamint a kívánt fordulatszámot beállító jelet (100 Hz-es PWM jel) kell biztosítani. A forgórészben 5 $\mathrm{db}$ állandó mágnes van elhelyezve, amelyek összesen 12 pólusra vannak felmágnesezve. Az 1. ábra a motor külső felépítését mutatja.

A motor állórészének 2 fázisú tekercsrendszere érdekes, a később említendő problémák fő forrása is lehet [2]. A tekercselés mellett felül a probléma forrása lehet még a csapágyak vezetőképességének forgás közbeni hiánya, változása (a forgórész esetleges árnyékoló hatását csökkentve ezzel), a nem megfelelő állórész vasmag anyag [3], valamint a mágnesek anyaga, elhelyezkedése és a vezérlőjelek tulajdonságai.

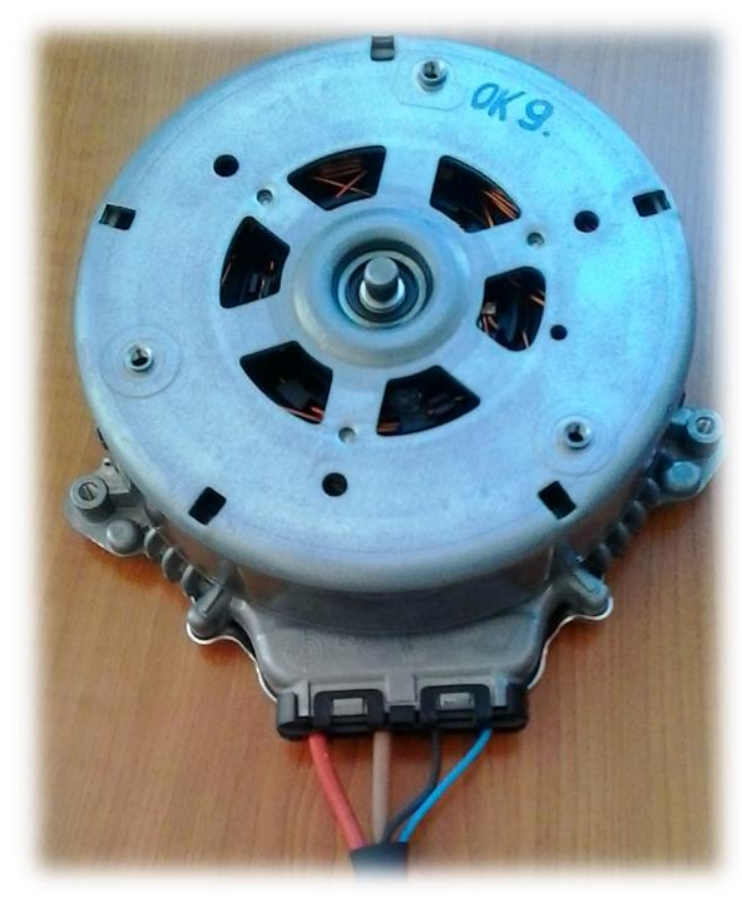

1. ábra. A vizsgált BLDC motor

\subsection{A környezet változása, célok, problémák megoldása}

A motor jelenleg megfelel a szükséges EMC direktíváknak, ám az új alkalmazási területek esetén, illetve egyes vevői igényeknél a kívánt elektromágneses zajkibocsátást már nem feltétlenül tudja teljesíteni [4]. Ezen felül minél összetettebb rendszerben alkalmazzuk (a modern autók egyre több elektronikát tartalmaznak), az egyes alkatrészek által kibocsátható szint annál kevesebb lehet [5]. A motor müködéséből adódóan a zajra nem érzékeny, viszont néhány kisebb frekvenciasávban egészen magas sugárzást bocsát ki.

A vizsgálatok célja, hogy a motorról olyan szintü modellt alkossak, amelyen a valódi müködés közbeni zaj vizsgálható. Ezzel a különböző módosítási kísérleteket fizikai megvalósítás nélkül is ki lehetne próbálni. A projekt előrehaladása szempontjából a kevés beavatkozást igénylő, de annál nagyobb eredményt hozó megoldásokat preferáljuk.

A korlátozott számítógépes erőforrások miatt a modell egyszerüsítése is egy érdekes terület. Itt első sorban a geometriai darabolások történtek meg, de néhány specifikus vizsgálatnál a különböző alkatrészek elhagyása is számottevő eredményt hozhat. 


\section{A motor térbeli modellje}

A motor térbeli modelljéhez egy kezdetleges modell a rendelkezésemre állt, azonban ez a modell elektronikai szempontból nem volt megfelelő. Nem tartalmazott gerjesztő tekercseket, a forgórész nem tartalmazta a mágneseket, illetve néhány alkatrész (amely a vizsgálat szempontjából fontos lehet) is hiányzott róla. A modellen definiáltam a különböző anyagokat, a szükséges gerjesztéseket, a mágneses tulajdonságokat beállítottam. A modell néhány paramétere úgy van beállítva, hogy forgást is lehessen szimulálni, viszont ez minden egyes lépésre nagyon időigényes, így megfontolandó, hogy megéri-e minden futtatáskor ilyen szintủ elemzést végrehajtani. A modell egy nézete látható a 2 . ábrán, néhány elem átlátszó a jobb átláthatóság kedvéért.

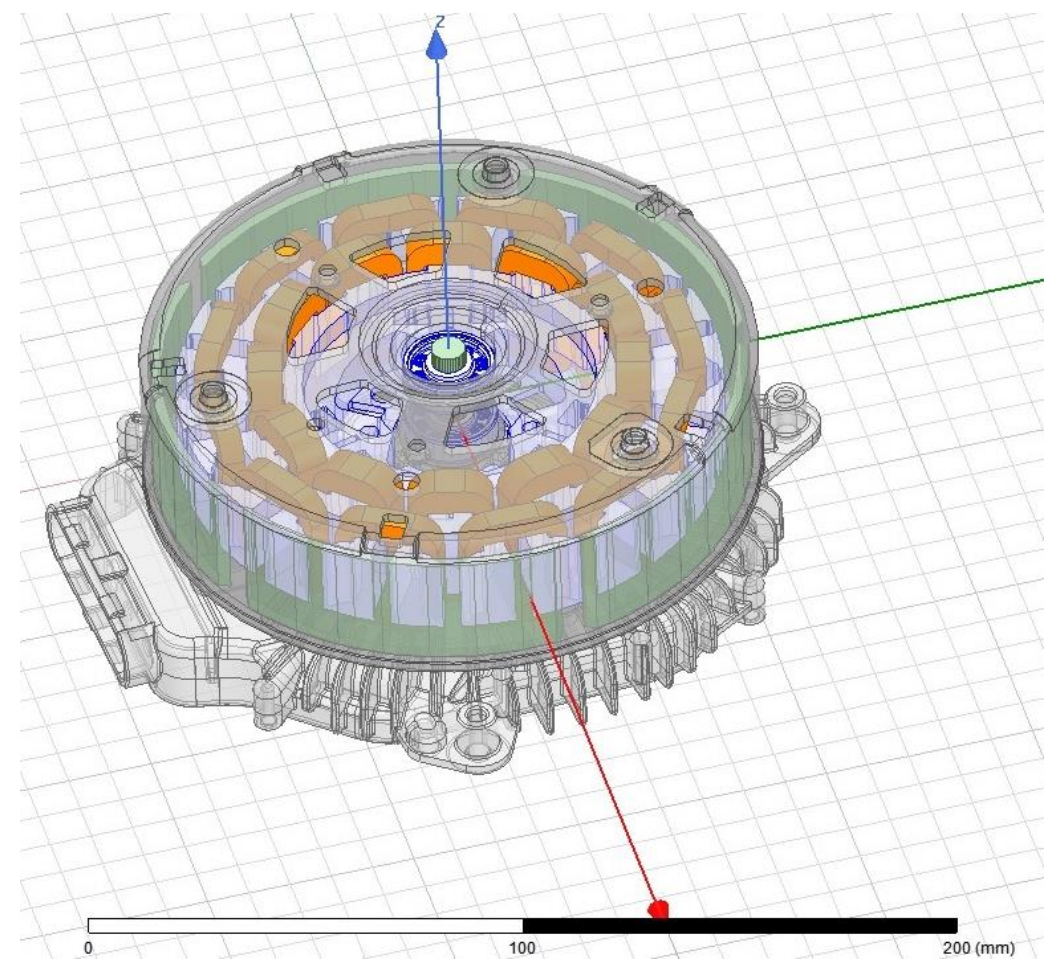

2. ábra. A motor 3D-s modellje

\subsection{Szimulációs eredmények}

Még korábban, egy másik elektromágneses szimulációt végző programban megrajzoltam ugyanennek a motornak a 2D-s modelljét. Tengelyszimmetrikus, illetve a motor alaplemezével párhuzamos síkban készítettem akkor el a szimulációkat. Ugyanezt a 3D-s modellen is el lehet végezni, csak az eredmények megjelenítési síkját kell megfelelően beállítani. Egy ilyen szimulációs eredményt mutat a 3. ábra. Ekkor még nem voltak csapágygolyók elhelyezve a modellben, illetve a forgórészt tartó tengely is hiányzott. Jól lehet viszont látni, ahogy a mágnesek környezetében jelentősen növekszik a mágneses térerősség (bal oldali jelölés), valamint azt ahogyan zárul a mágneses tér a forgórész közepénél, a vasmagon keresztül (jobb oldali jelölés).

Egy másik szimuláció esetében egy hiba folytán érdekes eredményt kaptam. A mágneses anyagok beállításánál minden mágnesszeletre külön kell definiálni az anyagtípust, mivel állandó mágnesnél 
csak így lehet a megfelelő (sugárirányú) mágneses irányítottságot elérni. Az egyik mágnesnél valamiért nem lett megfelelően beállítva a kívánt mágneses mező és ezt csak az eredménynél vettem észre. Ez az eset jól mutatja, hogy erősen sérül a mágneses mező szimmetriája hogyha nem megfelelő a felmágnesezés. Persze ez egy erősen túlzott példa, de ha nem eléggé szimmetrikus a mágneses mező, az mindenképpen befolyásolja a kibocsátott elektromágneses hullámokat (4. ábra). A mágneseket alkotó anyag pontos ismerete hiányában azt is feltételezhetjük, hogy bizonyos üzemállapotok esetén (magas hőmérséklet, nagy gerjesztőáram, mindez hosszú ideig) akár átmágnesezés is létrejöhet [6].

A mágnesek elhelyezése nem teljesen szimmetrikus a valódi motorok esetében, bár mivel a behelyezés után történik az átmágnesezés, így ez csak csekély problémát okozhat.

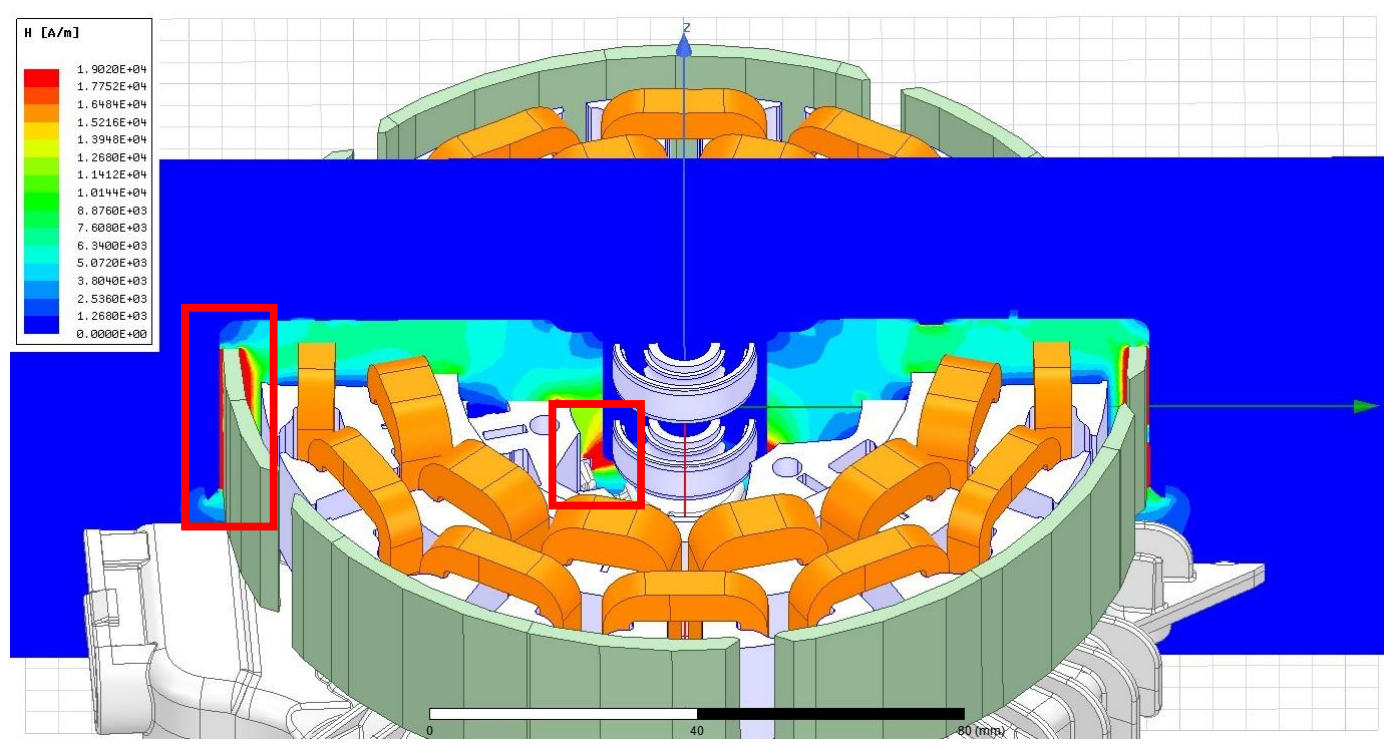

3. ábra. Szimulációs eredmények a tekercsek elektromos gerjesztése nélkül

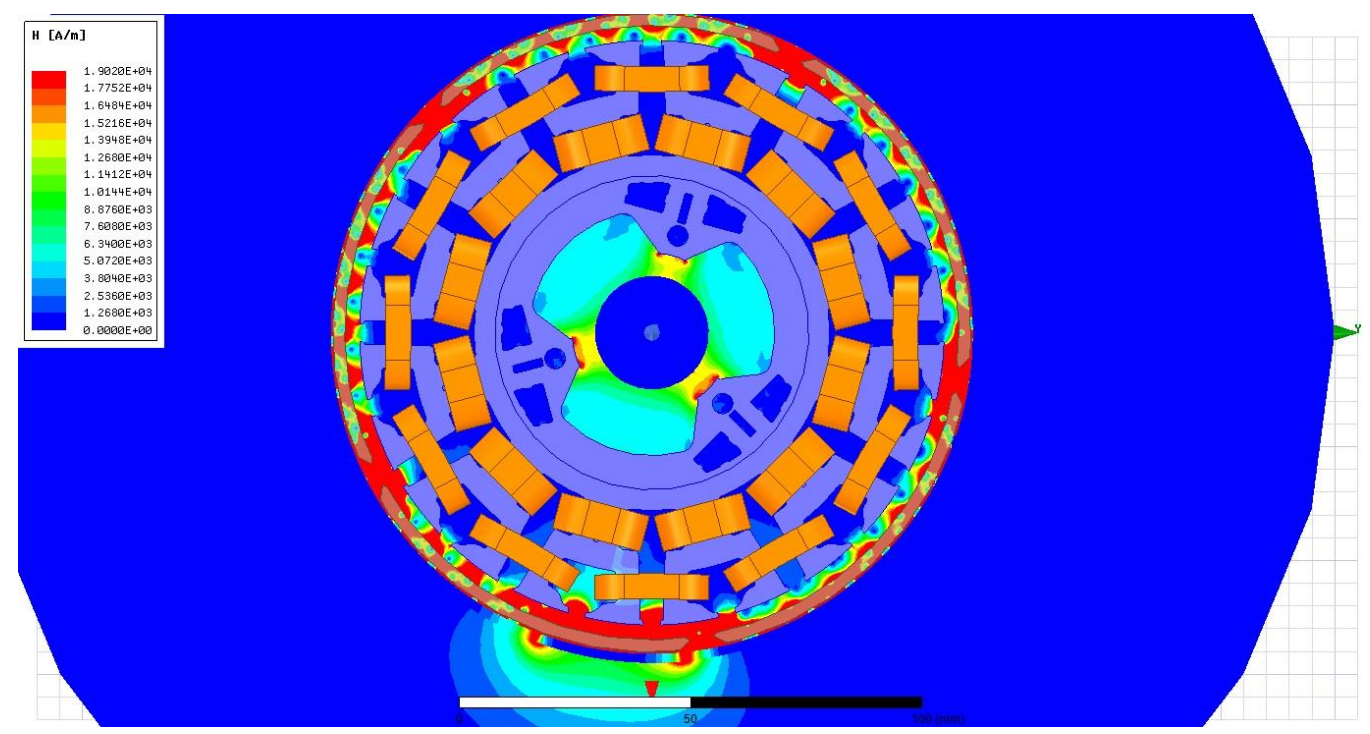

4. ábra. Mágneses mezö kitüremkedése szimmetria sértés esetén 


\subsection{Egyszerüsítési lehetőségek}

A modell komplexitásának növekedésével az egyes szimulációk kiszámítási ideje is jelentősen megnövekszik. Sok egyéb lehetőség mellett a legkézenfekvőbb megoldás a modell egyszerüsítése, vagy mondhatni feldarabolása. Szimmetrikusan 4 részre vágtam a teljes motort, így bár a vágási éleknél nem, de azon kívül még mindig egy használható eredményeket szolgáltató modellt kaptam. Ez a modell $1 \mathrm{db}$ teljes mágnest, valamint $5 \mathrm{db}$ teljes tekercset tartalmaz és jelentösen gyorsabban futtathatók rajta a különböző elemzések. A feldarabolt modell mágneses térerősségének egy síkbeli értékeit mutatja az 5. ábra.

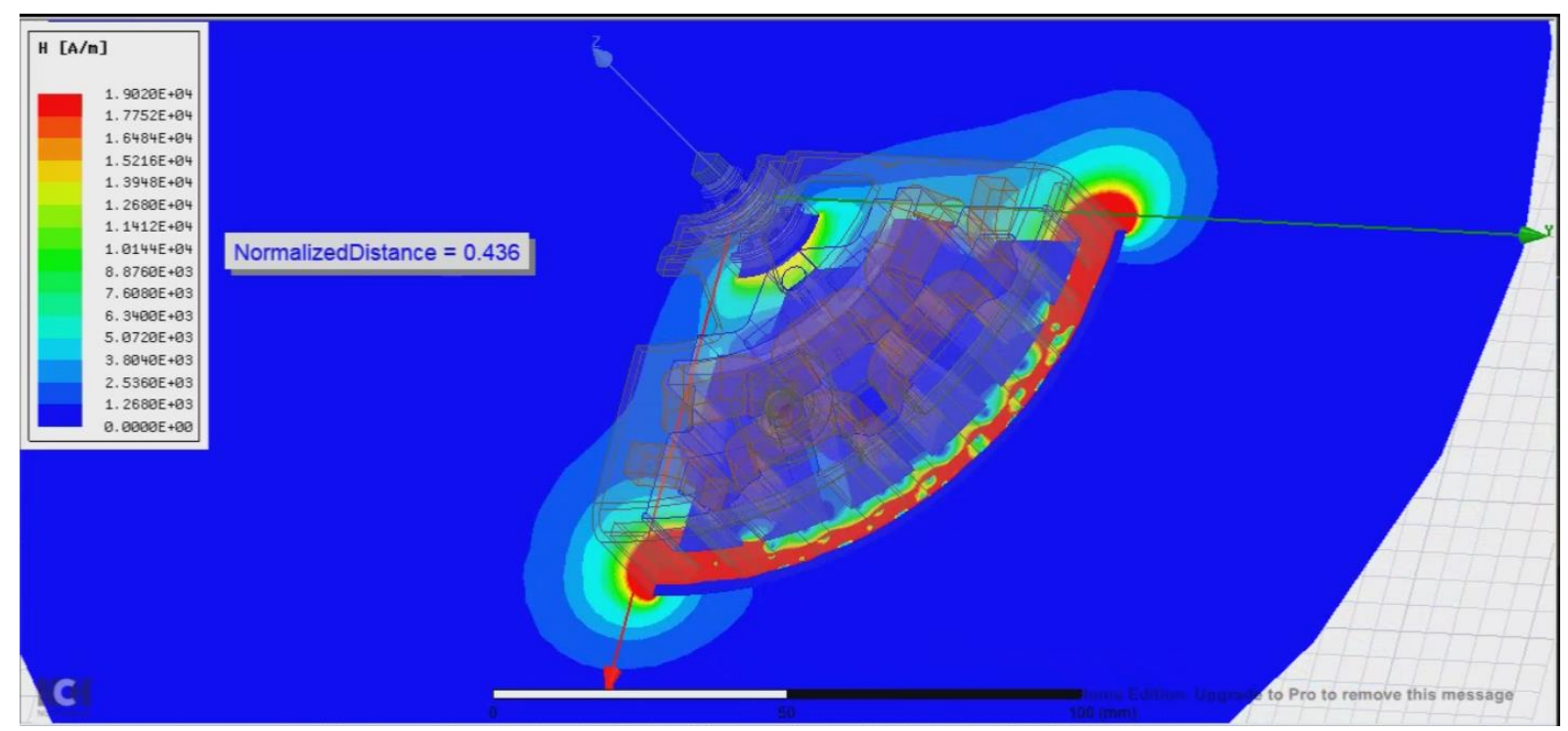

5. ábra. A feldarabolt modell mágneses térerösségértékei egy síkban

Az 5. ábrán „NormalizedDistance” felirat a metsző sík normalizált távolságát mutatja, mivel ez a nézet animált nézetből lett kivéve. Az animált nézet segítségével, mintha egy „laminográfiás képet” kapnánk, jobban elemezhető a különböző mennyiségek térbeli változása. Az animált nézet mellett a skála finomhangolása is sok információt tud nyújtani, az automatikus skála beállítás nem mindig célravezető, sok esetben, amire kíváncsiak vagyunk, nem jelenik meg, mivel a teljes tartományt jelöli ki és így az apró eltérések eltünnek.

\subsection{Fejlesztési célok}

Többféle mágnesezettségi értéket szükséges vizsgálni a forgórész esetén, mivel a mágnesezettség értékét nem állt módunkban megmérni. Az állórész gerjesztésével mindenképpen foglalkozni kell, jelenleg statikus gerjesztés van a tekercsekre beállítva, de az EMC probléma ilyen jellegü gerjesztésből nem adódhat.

A modell helyes müködéséhez a valódi gerjesztéssel megegyező gerjesztést kell beállítani, valamint a forgórész mozgását is meg kell valósítani. Jelenleg a vezérlöáramkör helye üres, szóval az alaplemez alatt nem található semmilyen alkatrész sem. Az alaplemez megfelelő felépítése is hozhat eredményt, de méréseink alapján nem túlságosan nagy befolyásoló tényező az áramkör jelenléte és müködése. Az utóbbi fejlesztési irányzatok jóval komolyabb feladatok, valamint a szimulációs idő rendkívül nagy mértékben növekszik megvalósításuk alkalmával. 
A modell fejlesztésén felül a motort folyamatosan vizsgáljuk a projekt keretein belül, így új eredmények esetén a további tervek is változhatnak.

\section{3. Összefoglalás}

A cikk célkitüzése egy autóipari BLDC motor modellezésének bemutatása volt. Az ANSYS program segítségével a motornak egy térbeli modelljén tudunk vizsgálatokat végezni, amely jelentős eredményeket hozhat akár az elektromágneses kompatibilitás vizsgálata esetén is. Egy jó modell lehetőséget ad számtalan paraméter ,költségek nélküli” vizsgálatára, de persze a modell összetettsége a számítási időt növeli. A cikkben bemutatott vizsgálati eredmények látványosan szemléltetik a modell további használatának előnyeit.

\section{Köszönetnyilvánítás}

A cikkben ismertetett kutató munka az EFOP-3.6.1-16-2016-00011 jelü „Fiatalodó és Megújuló Egyetem - Innovatív Tudásváros - a Miskolci Egyetem intelligens szakosodást szolgáló intézményi fejlesztése" projekt részeként - a Széchenyi 2020 keretében - az Európai Unió támogatásával, az Európai Szociális Alap társfinanszírozásával valósul meg.

A cikkben ismertetett kutató munka a GINOP-2.2.1-15-2017-00090 jelü „E-mobility Miskolcról: Hütővíz keringető szivattyú és motorhütő ventilátor továbbfejlesztése az elektromos jármüvekben elvárt magasabb minőségi követelmények figyelembevételével" projekt részeként - a Széchenyi 2020 keretében - az Európai Unió támogatásával, az Európai Szociális Alap társfinanszírozásával valósul meg.

\section{Irodalom}

[1] Yedamale, P.: "Brushless DC (BLDC) Motor Fundamentals," Microchip. Microchip, p. 20, 2004.

[2] Perez, R.: Handbook of Electromagnetic Compatibility. Academic Press, 2013.

[3] Saliovich, A.B.: Electromagnetic Shielding Handbook for Wired and Wireless Emc Applications. Kluwer Academic Pub, 1999.

[4] Rodriguez, V.: "Automotive component EMC testing: CISPR 25, ISO 11452-2 and equivalent standards," IEEE Electromagn. Compat. Mag., vol. 1, no. 1, pp. 83-90, 2012. https://doi.org/10.1109/MEMC.2012.6244955

[5] Marshman, C.: The guide to the EMC directive: 89/336/EEC, 36th ed. IEEE Press, 1992.

[6] Iványi, A.: Hysteresis Models in Electromagnetic Computation. Budapest, Akadémiai Kiadó, 1996. 